\title{
Carbon inputs of the Rhône River to the Mediterranean Sea: Biogeochemical implications
}

\author{
Richard Sempéré,' Bruno Charrière, ${ }^{2}$ France Van Wambeke, ${ }^{1}$ and Gustave Cauwet ${ }^{3}$
}

\begin{abstract}
Since the damming of the Nile, the Rhône River is the main freshwater and sediment supplier to the Mediterranean Sea. We estimated for the period 1987-1996, the dissolved and particulate organic carbon (DOC and POC), dissolved inorganic carbon (DIC), and total suspended matter (TSM) fluxes of the Rhône River to the Mediterranean Sea to be $1.1 \pm 0.2,1.6 \pm 0.5,16.2 \pm$ $0.3 \times 10^{10}$ moles $\mathrm{C} \mathrm{yr}^{-1}$, and $9.9 \pm 6.4 \times 10^{6} \mathrm{t} \mathrm{yr}^{-1}$, respectively. PIC flux was estimated to be $8.2 \pm$ $5.4 \times 10^{9}$ moles $\mathrm{C} \mathrm{yr}^{-1}$. On the basis of literature data, we estimated that nearshore bacterial respiration of Rhône derived labile-POC and -DOC (LPOC and LDOC) might produce in a few days $\sim 0.21$ and $0.12 \times 10^{10}$ moles $\mathrm{CO}_{2} \mathrm{yr}^{-1}$, respectively. Extended to the whole Mediterranean, this study suggests that bacterial respiration of labile organic carbon derived from Mediterranean rivers might rapidly (days) produce $2.6-11 \times 10^{10}$ moles $\mathrm{CO}_{2} \mathrm{yr}^{-1}$. On the continental shelf, up to $4.7 \times 10^{10}$ moles of organic carbon introduced by primary production and Rhône export would escape each year to sedimentation and bacterial mineralization and would be exported off the shelf. Moreover, as total carbon fixed by phytoplankton exceeds $\left(+5.2 \times 10^{10}\right.$ moles $\left.\mathrm{C} \mathrm{yr}^{-1}\right)$ the $\mathrm{CO}_{2}$ produced by bacterial respiration (on average), the biological system on the shelf, could be considered as an autotrophic system and then a sink for atmospheric $\mathrm{CO}_{2}$. However, these numbers need further examination because of the large uncertainties associated currently to the bacterial growth efficiency values $( \pm 100 \%)$.
\end{abstract}

\section{Introduction}

Among fluxes, river inputs of carbon to the ocean are of interest because atmospheric/soil $\mathrm{CO}_{2}$ is consumed both by primary producers and chemical rock weathering before being transferred as inorganic [Berner et al., 1983; Berner, 1990; Meybeck, 1987; Probst et al., 1994; Ludwig et al., 1996a] and organic carbon to the oceans [Meybeck, 1982; Ittekot, 1988; Ludwig et al., 1996b]. In addition, riverine inputs are unidirectional fluxes and are affected by numerous natural factors such as precipitations, morphology, and mean temperature [Miller and Russel, 1992; Ludwig et al., 1996b; Clair and Ehrman, 1996; Justic et al., 1996] as well as by anthropogenic factors such as land uses [Kao and Liu, 1996; 1997]. Moreover, river inputs play a significant role on water quality and fisheries production of the coastal zone which accounts for $10 \%$ of global oceanic primary production [Smith and Hollibaugh, 1993]. However, the material carried by the rivers undergoes reactions and modifications during transport such as aggregation [Sholkovitz, 1976] and transformations due to bacterial metabolism [Richey et al., 1980;

\footnotetext{
${ }^{1}$ Laboratoire de Microbiologie Marine, CNRS/INSU EP 2032, Campus de Luminy, Université de la Méditerranée, Marseille, France.

${ }^{2}$ Centre de Formation et de Recherche sur l'Environnement Marin, CNRS/INSU ERS 1745, Perpignan, France.

${ }^{3}$ Laboratoire d'Océanographie Biologique, UMR 7621, Laboratoire Arago, Banyuls sur mer, France.
}

Copyright 2000 by the American Geophysical Union.

Paper number 1999GB 900069

0886-6236/00/19999GB900069\$12.00
Ittekot, 1988; Amon and Benner, 1996] which make carbon fluxes difficult to estimate accurately for regions where no measurements exist.

Freshwater inputs play a major role in the Mediterranean Sea since they enhance significantly the primary productivity [Cruzado and Velasquez, 1990] and play a major role in the balance of water inputs through the Strait of Gibraltar [Bryden and Kinder, 1988; Copin-Montégut, 1993; Bray et al., 1995]. The net inflow through the Strait ranges from 1400 to $2400 \mathrm{~km}^{3} \mathrm{yr}^{-1}$ [Bryden and Kinder, 1988], whereas those from the Black Sea through the Bosphorus and Dardanelles is $300 \mathrm{~km}^{3} \mathrm{yr}^{-1}$ [Ünlüata et al., 1990]. The discharge of rivers into the Mediterranean Sea averages $505 \mathrm{~km}^{3} \mathrm{yr}^{-1}$ [Margat, 1992]. An accurate determination of the sources and sinks of carbon is still necessary to assess more accurately the carbon cycle in the Mediterranean Sea [Copin-Montégut, 1993]. Since the damming of the Nile, the Rhône River is the major source of fresh water and terrigenous particles to the Mediterranean basin [Margat, 1992]. However, only few reports address the DOC input [Cauwet et al., 1990; Kempe et al., 1993; Sempéré and Cauwet, 1993], and there are no published data of measured Rhône total organic carbon (TOC) including POC and DOC as well as DIC fluxes to the Mediterranean Sea that encompass a complete hydrological year.

Here we report results from a one-year time series (June 1994 to May 1995) which assesses, for the first time, temporal patterns in the DOC, POC, TSM, and DIC loads of the Rhône River. Using these data, we estimated carbon fluxes by the Rhône River into the Mediterranean Sea during this period. After linear regressions, these fluxes were extended to 10-year average annual fluxes, we finally propose an estimate of the average input of these variables to the Mediterranean Sea. 


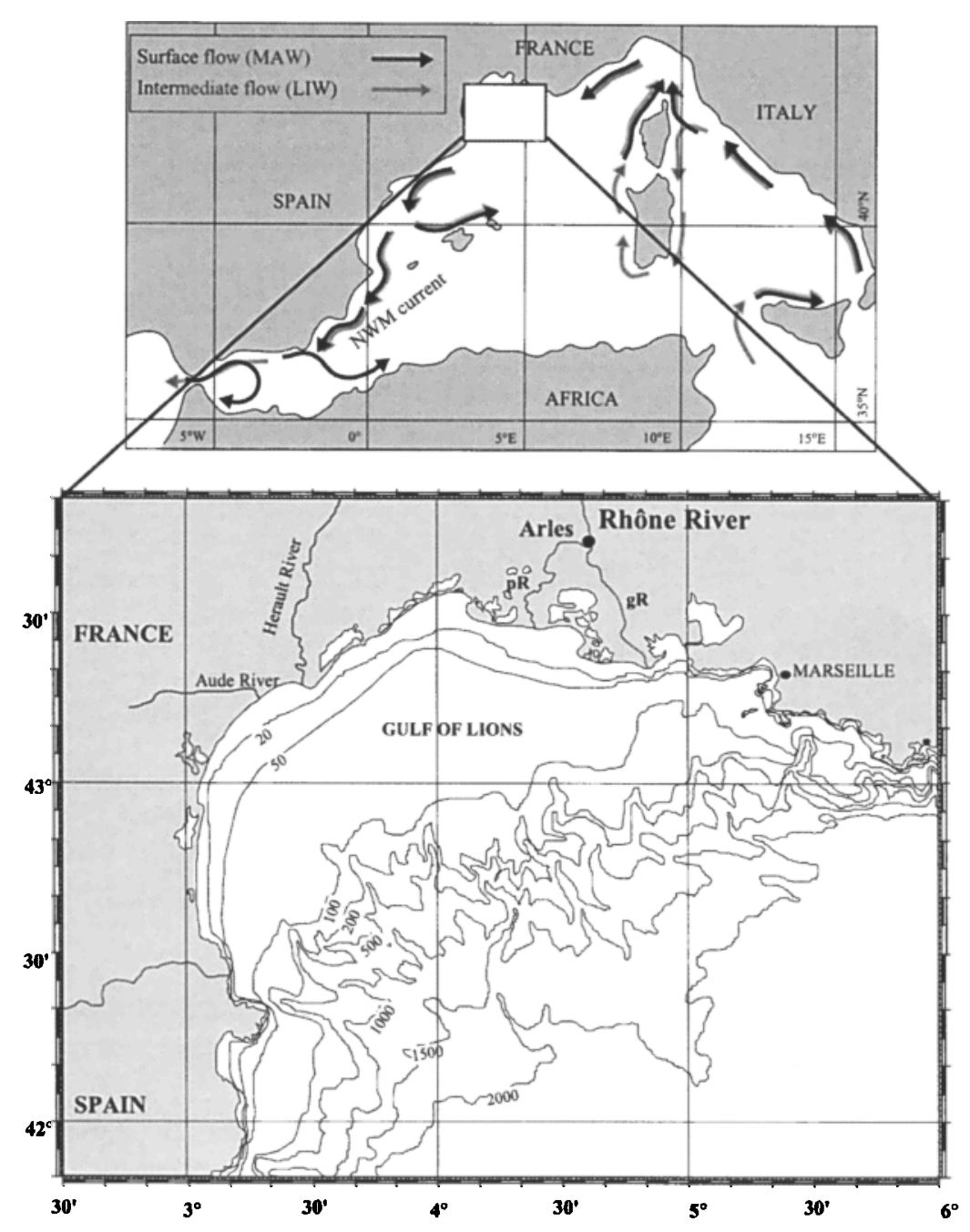

Figure 1. Rhône River Mouth area and sampling location 'A' during the period of June 1994 to May 1995. Here $\mathrm{gR}$ and $\mathrm{pR}$ mean grand Rhône and petit Rhône, which are the two functional arms of the main River. Surface and intermediate circulations in the western Mediterranean Sea are indicated. Cyclonic current in the northern basin is called the northwestern Mediterranean (NWM) current [after Millot, 1987]. (Redrawn from [Yoro et al. 1997]).

\section{Materials and Methods}

\subsection{Area}

The Rhône River is $816 \mathrm{~km}$ long and has a drainage area of $\sim$ $97,800 \mathrm{~km}^{2}$ (Figure 1). The mean river discharge measured near Beaujeu (65 km from the mouth) from 1965 to 1997 was found to be $54 \mathrm{~km}^{3} \mathrm{yr}^{-1}$ [Pont, 1997]. At $40 \mathrm{~km}$ from the sea, the river splits into two branches so-called the "Grand Rhône" and the "Petit Rhône" carrying 90 and $10 \%$ of the total discharge, respectively [Ibanez et al., 1997, and references therein]. The 10year mean annual precipitation (1987-1996) monitored at the city of Arles ranges from 262 to $886 \mathrm{~mm} \mathrm{yr}^{-1}$ (Météo-France, 1998). The estuary can be characterized by a high water discharge rate per unit width, shallow depths and relatively weak tidal currents and then corresponds to a type 4 or a salt-wedge estuary [Ibanez et al., 1997] according to the Hansen and Rattray [1966] classification. The Rhône River discharge takes place in the continental shelf of the Gulf of Lions in the northwestern Mediterranean Sea (Figure 1)

\subsection{Sampling}

To monitor temporal variations of TSM, POC, DOC, and DIC in the river water over the course of the year, surface water samples were collected $\sim 1$ to 5 times a month from June 1994 to May 1995 at the Rhône River reference estuarine station (Arles) $40 \mathrm{~km}$ upstream from the river mouth (Figure 1). Samples were withdrawn by using glass bottles cleaned prior to utilization with $\mathrm{HCl} 2 \%$ and Milli-Q water. After collection, water was filtered in the laboratory under reduced vacuum through an all glass precombusted $\left(450^{\circ} \mathrm{C}\right.$ for 6 hours) fibre filter $(47 \mathrm{~mm}-\mathrm{GF} / \mathrm{F}$ with a porosity of $0.7 \mu \mathrm{m})$. Two aliquots of filtrate were stored in the dark with a bactericide $\mathrm{HgCl}_{2}\left(10 \mathrm{mg} \mathrm{L} \mathrm{L}^{-1}\right)$ in precombusted $\left(450^{\circ} \mathrm{C}\right.$ for 6 hours) $10-\mathrm{mL}$ glass vials with Teflon-lined screw caps prior to analyses of DIC and DOC. After filtration, filters were washed with Milli-Q water to eliminate salts, and dried for 24 hours at $50^{\circ} \mathrm{C}$. The dry weight of collected suspension was used to calculate TSM, whereas the filters were analyzed for POC determination Mean daily river discharge for the calculations of the fluxes were obtained from D. Pont (CNRS, Arles) 
Table 1. Total Suspended Matter (TSM), Particulate Organic Carbon (POC), Dissolved Organic Carbon (DOC), Dissolved Inorganic Carbon (DIC) and DOC/POC Ratios Measured in the Rhône River During the Period June 1994 to May 1995

\begin{tabular}{|c|c|c|c|c|c|c|}
\hline Date & $\begin{array}{c}\text { Discharge, } \\
\mathrm{m}^{3} \mathrm{~s}^{-1}\end{array}$ & $\begin{array}{l}\text { TSM, } \\
\text { mg L }^{-1}\end{array}$ & $\begin{array}{c}\text { POC, } \\
\mu \mathrm{M}\end{array}$ & $\begin{array}{c}\mathrm{DOC}, \\
\mu \mathrm{M}\end{array}$ & $\begin{array}{l}\text { DIC, } \\
\mu \mathrm{M}\end{array}$ & $\underset{\text { Ratio }}{\text { DOC/POC }}$ \\
\hline June 21, 1994 & 1507 & 15 & 77 & 158 & 2568 & 2.0 \\
\hline July 5,1994 & 1646 & 18 & 47 & 143 & 2243 & 3.0 \\
\hline July 19,1994 & 1170 & 35 & 49 & 133 & 2071 & 2.7 \\
\hline Aug. 2, 1994 & 1296 & 16 & 34 & 140 & 2088 & 4.1 \\
\hline Aug. 16, 1994 & 833 & 11 & 38 & 150 & 2041 & 3.9 \\
\hline Aug. 30, 1994 & 874 & 10 & 29 & 158 & 2143 & 5.5 \\
\hline Sept. 13, 1994 & 2459 & 73 & 102 & 180 & 2328 & 1.7 \\
\hline Sept. 15, 1994 & 3212 & 293 & 347 & 220 & 2338 & 0.6 \\
\hline Sept. 20, 1994 & 2359 & 132 & 201 & 293 & 2888 & 1.5 \\
\hline Sept. 25,1994 & 3188 & 554 & 771 & 313 & 2486 & 0.4 \\
\hline Sept. 29, 1994 & 2212 & 410 & 288 & 186 & 2745 & 0.7 \\
\hline Oct. 11, 1994 & 1295 & 23 & 36 & 177 & 2813 & 4.9 \\
\hline Oct. 21, 1994 & 6373 & 799 & 1650 & 319 & 1873 & 0.2 \\
\hline Oct. 25,1994 & 2173 & 114 & 120 & 234 & 2705 & 1.9 \\
\hline Nov. 6,1994 & 9430 & 7310 & 5483 & 344 & 2555 & 0.1 \\
\hline Nov. 8, 1994 & 5164 & 1165 & 1146 & 226 & 2706 & 0.2 \\
\hline Nov. 11,1994 & 4537 & 1019 & 730 & 386 & 2763 & 0.5 \\
\hline Nov. 22,1994 & 2301 & 46 & 126 & 199 & 4169 & 1.6 \\
\hline Dec. 6,1994 & 1265 & 16 & 55 & 146 & 3533 & 2.7 \\
\hline Dec. 19,1994 & 1270 & 18 & 91 & 206 & 3822 & 2.3 \\
\hline Jan. 4, 1995 & 2304 & 74 & 337 & 212 & 3805 & 0.6 \\
\hline Jan. 17, 1995 & 2735 & 84 & 362 & 212 & 3614 & 0.6 \\
\hline Jan. 24,1995 & 3531 & 91 & 342 & 193 & 3588 & 0.6 \\
\hline Jan. 25,1995 & 4244 & 243 & 638 & 197 & 3590 & 0.3 \\
\hline Feb. 1, 1995 & 4614 & 189 & 568 & 218 & 3363 & 0.4 \\
\hline Feb. 9, 1995 & 2824 & 47 & 276 & 274 & 3549 & 1.0 \\
\hline Feb. 19, 1995 & 2863 & 39 & 177 & 303 & 3533 & 1.7 \\
\hline Feb. 21, 1995 & 3741 & 110 & 413 & 225 & 3498 & 0.5 \\
\hline Feb. 28, 1995 & 4895 & 299 & 748 & 238 & 3466 & 0.3 \\
\hline Mar. 14, 1995 & 2174 & 28 & 125 & 218 & 3761 & 1.7 \\
\hline Mar. 27, 1995 & 2616 & 56 & 276 & 236 & 3478 & 0.9 \\
\hline April 11, 1995 & 1971 & 38 & 159 & 192 & 3485 & 1.2 \\
\hline April 25, 1995 & 4624 & 1119 & 1501 & 221 & 3423 & 0.2 \\
\hline May 9,1995 & 1893 & 43 & 125 & 189 & 3228 & 1.5 \\
\hline May 16, 1995 & 2644 & 91 & 203 & 163 & 3128 & 0.8 \\
\hline Mean & 2921 & 418 & 505 & 217 & 3011 & 0.4 \\
\hline Standard deviation & 1737 & 1224 & 941 & 60 & 623 & 0.1 \\
\hline
\end{tabular}

\subsection{Measurements of DIC, DOC, and POC in Water Samples}

DIC was determined by using a Shimadzu 5000 HTC analyzer ("inorganic carbon" mode) equipped with an infrared detection cell. The characteristics of the TOC 5000 for DIC determination are consistent with previous expertise elaborated by Tanoue [1992]. The analytical error was within $0.5 \%$.

DOC was measured by a Shimadzu 5000 HTC analyzer ("nonpurgeable organic carbon" mode) equipped with a catalyst made of $1.2 \%$ of Pt on silica pillows [Cauwet, 1994]. Briefly, the analytical precision of the procedure was within $2 \%$, but variability between data obtained from two different vials from the same samples gives rise to a lower precision (4-6\%). The instrument blank (5-10 $\mu \mathrm{M} \mathrm{C}$ ) was subtracted from all measured values. Other analytical details are given elsewhere [Cauwet, 1994; Thomas et al., 1995].

POC was measured by dry combustion of the filters [Tan and Strain, 1979]. After having been dried and weighed, the filters were folded into crucibles, impregnated with $2 \mathrm{M} \mathrm{HCl}$ and dried at $50^{\circ} \mathrm{C}$ to remove carbonates and most of the remaining acid and water. The filters were then assayed on a $\mathrm{CHN}$ analyzer (CHN$800 \mathrm{LECO}$ ) with a combustion tube at $850^{\circ} \mathrm{C}$. The $\mathrm{CO}_{2}$ generated by oxidation was measured by a NDIR cell with a standard deviation of $2 \%$.

\section{Results}

\subsection{Water Discharge, TSM, and POC Concentrations}

During the sampling period (June 1994 to May 1994), the discharge rate of the Rhône River significantly fluctuated (Table 1, Figure 2). Strong annual variations were also observed for the 1987-1996 period (Table 2). This highlights that the annual Rhône freshwater supply to the Mediterranean Sea can vary by a factor of 2.

TSM and POC concentrations (Table 1) ranged from 10 to $7310 \mathrm{mg} \mathrm{L}^{-1}$ and from 29 to $5483 \mu \mathrm{M} \mathrm{C}$, respectively. POC expressed as a percentage of TSM (POC\% $=100 \times$ POC/TSM) 


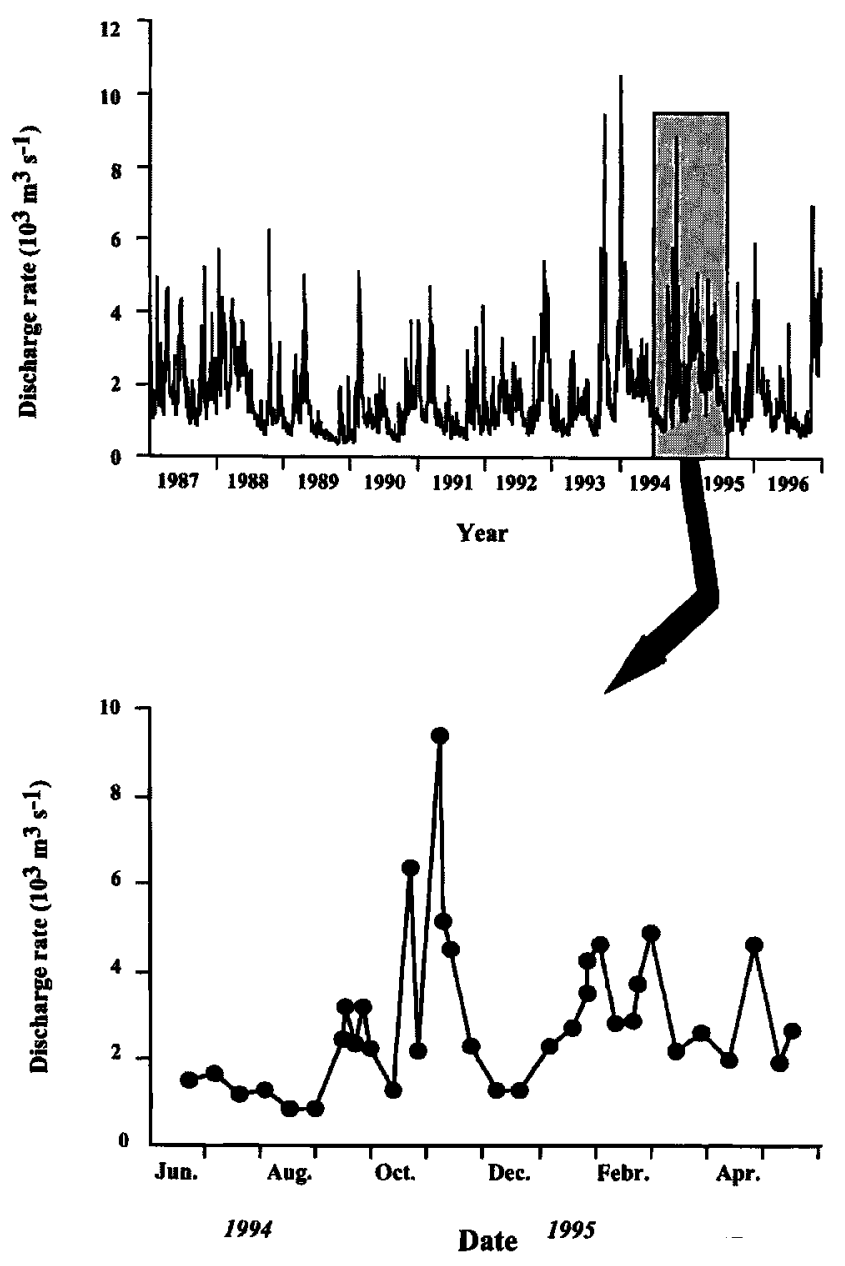

Figure 2. Daily mean discharge rate in $10^{3} \mathrm{~m}^{3} \mathrm{~s}^{-1}$ at the sampling station (City of Arles), January 1987 to December 1996. ranged from 0.84 to 7.1 (Fig. 3), the minimum being observed in highly turbid waters and vice versa. The inverse relationship between POC\% and TSM mainly results from the dilution of autochthonous organic particles by land-derived material and resuspended particles [Meybeck, 1982; Ittekot, 1988].

\subsection{DOC and DIC Concentrations}

DOC concentrations (Table 1) averaged $217 \pm 61 \mu \mathrm{M} \mathrm{C}$. Previous studies in the same area, reported similar DOC concentrations [Cauwet et al., 1990; Sempéré and Cauwet, 1993] which are typical for a temperate zone $(250 \mu \mathrm{M} \mathrm{C}$ [Meybeck, 1982]). On a monthly basis, the highest DOC/TOC ratios (67$82 \%$ ) were observed in summer 1994 and the minimum value (13\%) in November 1994 which was characterized by a particularly high discharge rate. This indicates that the influence of discharge is higher on POC than on DOC transport. DIC concentrations (Table 1) averaged $2995 \pm 575 \mu \mathrm{M}$ C. Since bicarbonate is the inorganic carbon species in fresh waters, our DIC concentrations are very close to those reported for alkalinity in the Rhône River ( $2890 \mu \mathrm{M}$ [Ministère de l'Environnement, 1980]).

\subsection{Relations Between the Discharge and TSM, POC, DIC, and DOC}

The daily TSM load as well as POC, DOC, and DIC loads were calculated by multiplying their concentrations by the daily discharge rate observed during the sampling period. The discharge rate (Figure 2) as well as the TSM, POC, DOC, and DIC fluxes (Figures 4a-4d) varied concomitantly suggesting that the concentration of these parameters are controlled by the water discharge. The transport during the heavy rainfall of November 1994 was by far the most important we observed during the year. The volume of the streamflow during November 1994 was 13.9 $\mathrm{km}^{3}$, accounting for $17 \%$ of the yearly discharge $\left(82 \mathrm{~km}^{3}\right)$ observed during the sampling period (1994-1995), whereas for the

Table 2. Annual Rhône River Discharge, and Fluxes of Total Suspended Matter (TSM), Particulate Organic Carbon (POC), Dissolved Organic Carbon (DOC), Dissolved Inorganic Carbon (DIC) and Particulate Inorganic Carbon (PIC; assuming a PIC/TSM ratio of 0.01 [Meybeck, 1982]) During the Period 1987-1996

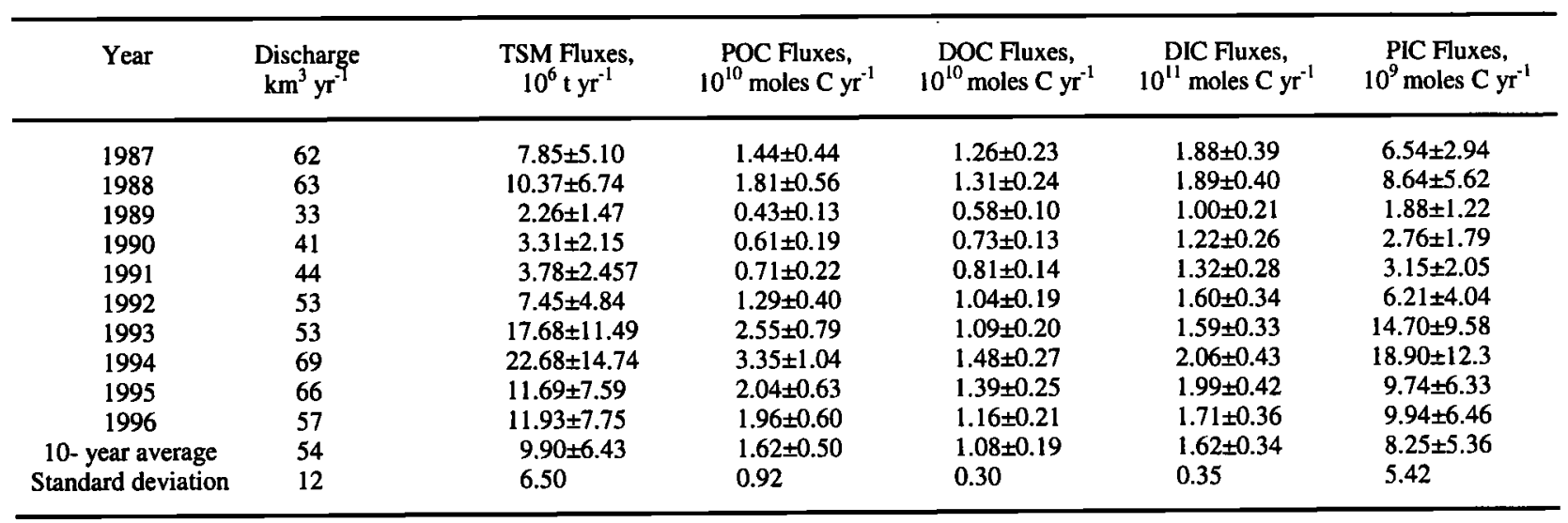

The TSM, POC, and DOC fluxes were calculated from the log/log relationships between the daily Rhône River discharge and corresponding loads based on 35 points between June 1994 and May 1995 and corrected by multiplying them with (C) the Ferguson [1987] factor. C = exp(2.651 $\mathrm{sd}^{\wedge} 2$ ), with sd, standard error of estimate of the regression of Ferguson [1987]. Values of C were 1.300 for TSM, 1.076 for the POC, and 1.017 for DOC. DIC fluxes were obtained by multiplying an averaged DIC concentration by daily discharge rate. 


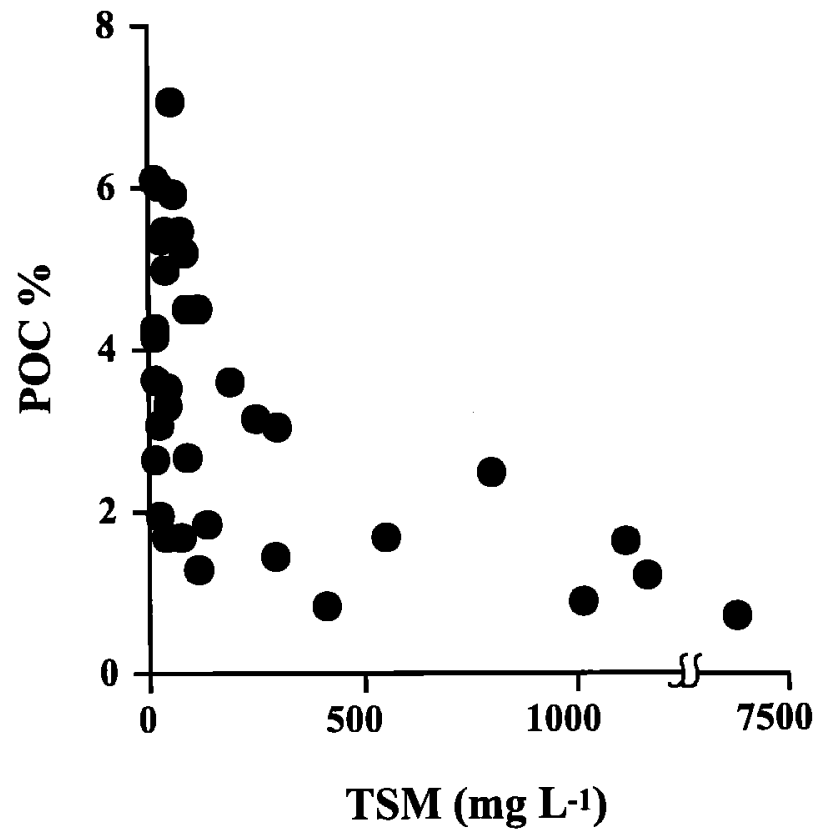

Figure 3. Relationship between TSM concentrations and percentages of organic carbon in particulate matter (POC\%) at the sampling station during June 1994 to May 1995. Samples collected during heavy rainfall (November 1994) are off scale.

same period TSM and POC transports accounted for 72 and $51 \%$ of their yearly transport, respectively. By contrast, concentrations of TSM, POC, and DOC were well correlated with the daily discharge rate $(\mathrm{Q})$ in a $\log -\log$ plot (Figures $5 \mathrm{a}-5 \mathrm{c}$ ). The best logarithmic regressions $(n=35)$ are

$$
\begin{aligned}
& \log (\mathrm{TSM})=-6.469+2.484 \times \log Q \quad r^{2}=0.791 \\
& \log (\mathrm{POC})=-4.859+2.119 \times \log Q \quad r^{2}=0.908 \\
& \log (\mathrm{DOC})=+1.141+0.347 \times \log Q \quad r^{2}=0.538 .
\end{aligned}
$$

TSM is given in $\mathrm{mg} \mathrm{L} \mathrm{L}^{-1}, \mathrm{POC}$ and DOC in $\mu \mathrm{M} \mathrm{C}$ and $\mathrm{Q}$ is in $\mathrm{m}^{3} \mathrm{~s}^{-1}$. The regression coefficients are much higher for TSM and POC (2.484 and 2.119) than for DOC (0.347), indicating that high discharge induces a more pronounced mobilization from the soils than it does for dissolved carbon. From these relationships, we calculated TSM, POC, and DOC fluxes for each day from the daily discharge rate recorded from 1987 to 1996 (annual fluxes calculated for this period are given in Table 2). Then the fluxes of TSM, DOC, and POC were corrected by the factor of Ferguson [1987; Table 2]. This method was found to significantly improve accuracy of river loads [Smith et al., 1996]. As $\log / \log$ relationship was found to be not significant, DIC transports were estimated by multiplying average concentration by the corresponding river discharge. The DIC error is given by the standard deviation found for average DIC concentration. The mean relative standard deviation was defined as the root of the weighted mean-square of the coefficients of variation between calculations and observations of 1994-1995 collected samples (Figures 4a-4d). The errors were arbitrarily attributed to all transport estimates from 1987 to 1996.

\subsection{TSM, POC, DOC, DIC, and PIC Transports}

The averaged calculated (1987-1996) TSM and POC transports were $9.9 \pm 6.4 \times 10^{6} \mathrm{t} \mathrm{yr}^{-1}$ and $1.6 \pm 0.5 \times 10^{10}$ moles $\mathrm{C} \mathrm{yr}-1$, respectively. These figures are higher than TSM and POC transports reported by Cauwet et al. [1990] for 1986-1987 (2. 8 x $10^{6} \mathrm{t} \mathrm{yr}^{-1}$ and $0.66 \times 10^{10}$ and moles $\mathrm{C} \mathrm{yr}^{-1}$ ), but this study is related to a limited number of samples during a rather dry period $\left(53 \mathrm{~km}^{3} \mathrm{yr}^{-1}\right)$. By contrast, TSM fluxes given for the Rhône River by Milliman and Syvitsky [1992] (31 x 106 $\left.\mathrm{tyr}^{-1}\right)$ are probably overestimated since long time series (1961-1997) published by Pont [1997] indicates rather an annual flux of TSM fluxes average $6.2 \times 10^{6} \mathrm{t} \mathrm{yr}^{-1}$. One can note also that the POC input is slightly higher than the DOC input during a "humid period" (river discharge $>50 \mathrm{~km}^{3} \mathrm{yr}^{-1}$ (Table 2)). Nevertheless, over 1987 $1996,60 \%$ of TOC occurred as POC.

For the 1987-1996 period, organic content of particles (POC\%; Figure 3 ) averaged $2.5 \pm 0.2 \%$. It should be noticed that the TSM flux to the coastal zone includes not only riverborne particles and detrital material from the land but also a significant fraction of fossil carbon of sedimentary rocks. However, by using isotope decay, the mean age of this mixture of particles was estimated to range from one to a few years by Thomas [1997], indicating that old sedimentary carbon is not important in the overall riverine POC fluxes as this has been also pointed out by Ludwig et al. [1996b].

The calculated average DOC flux was found to be $1.1 \pm 0.2 \mathrm{x}$ $10^{10}$ moles $\mathrm{C} \mathrm{yr}^{-1}$, which is very close to the value (0.8-1.1 $\mathrm{x}$ $10^{10}$ moles $\mathrm{C} \mathrm{yr}^{-1}$ ) estimated by Cauwet et al. [1990] from a limited number of samples. It should be noticed that like sedimentation of most land-derived particulate materials in estuarine waters, flocculation is also likely to occur [Sholkovitz, 1976] trapping land-derived dissolved organic matter before entering into typical marine waters. Loss of less than $7 \%$ of DOC has been reported by Mantoura and Woodward [1983] for the Severn Estuary. The averaged calculated DIC transport was found to be $1.6 \pm 0.3 \times 10^{11}$ moles $\mathrm{C} \mathrm{yr}^{-1}$, which is close to the estimate (1.5 x $10^{11}$ moles $\mathrm{C} \mathrm{yr}^{-1}$ ) given by Copin-Montégut [1993] from alkalinity data. If we assume that particulate inorganic carbon (PIC) represents $~ 1 \%$ of TSM [Meybeck, 1982], then averaged (1987-1996) global input of PIC from the Rhône River to the Mediterranean Sea would be $8.2 \pm 5.4 \times 10^{9}$ moles $\mathrm{C} \mathrm{yr}^{-1}$, leading to a total inorganic carbon (TIC) flux of $17.0 \pm 5.7 \times 10^{10}$

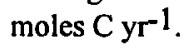

\section{Discussion}

\subsection{Fluxes of Carbon From the Rhône River to the Mediterranean Sea}

In comparison to the broad estimates given by Copin-Montégut [1993] and Ludwig et al. [1998] for the Mediterranean Rivers, our results indicate that the Rhône River accounts for 3-14 and 10$12 \%$ of the overall TOC and TIC river inputs to the Mediterranean Sea (including the Black Sea). These results indicated the dominance of bicarbonates (82\%) over the other carbon species (PIC, 4\%; DOC, 6\%; POC, 8\%) in the Rhône River (Figure 6). Note that the relative abundance of the carbon species are significantly different from that reported for the overall river carbon input to the world's oceans (bicarbonate, $45 \%$; DOC, $26 \%$; POC, 29\%). The ratio $\left(R_{10}\right)$ of bicarbonate to organic 

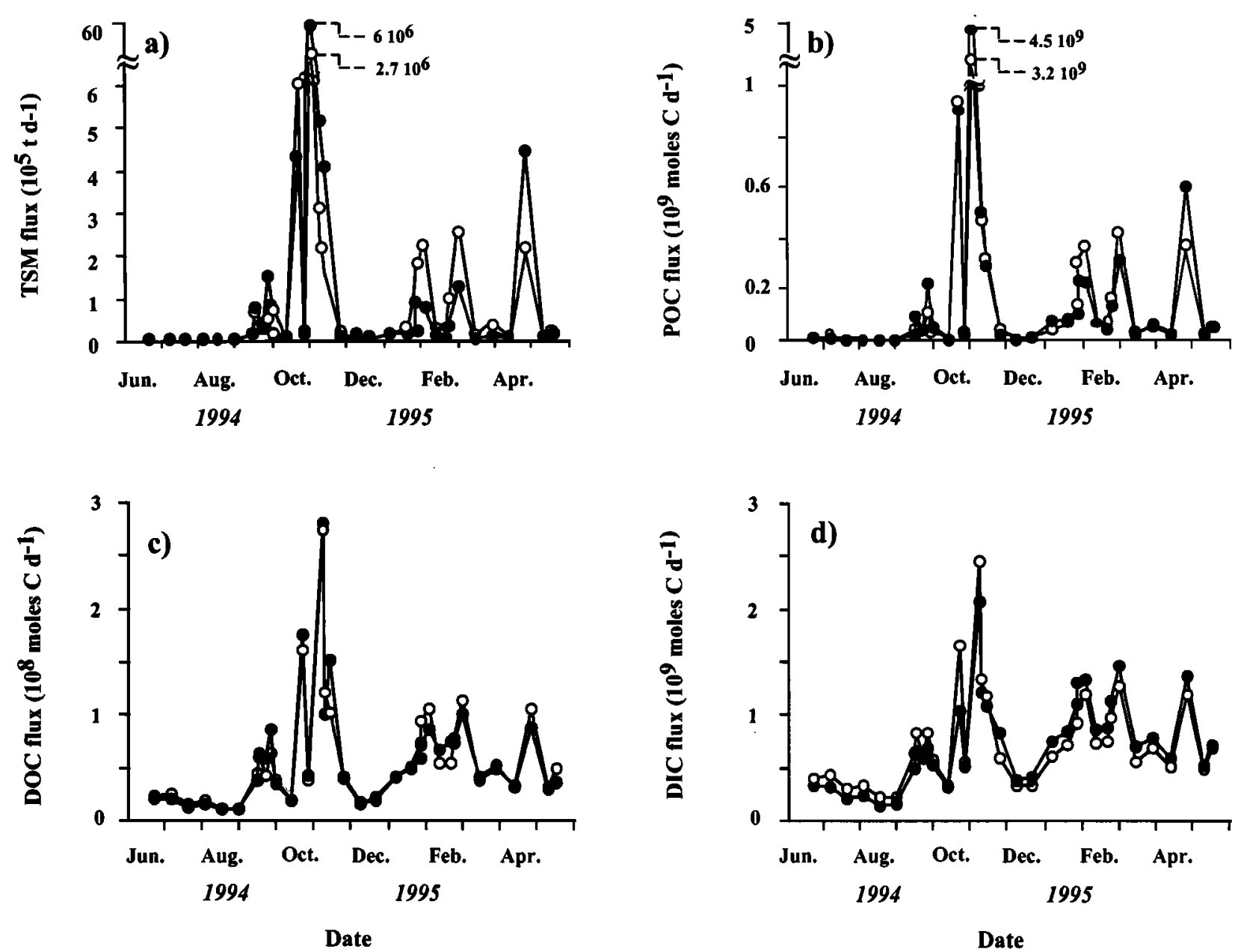

Figure 4. (a) TSM flux in $\mathrm{t} \mathrm{d}^{-1}$, (b) POC, (c) DOC and (d) DIC fluxes in moles $\mathrm{C} \mathrm{d}^{-1}$ at the sampling station during June 1994 to May 1995. Open circles represent the observed fluxes; solid circles represent calculated fluxes determined from the discharge rate by using $\log / \log$ relationships (TSM, POC, and DOC) or average DIC concentration multiplied by daily discharge rates (see also comments on Figure 5 and Table 2).

(DOC+POC) carbon averaged $6.8 \pm 1.9$ on an annual basis, the highest ratios being found for lower discharges. The variability of the Rhône River- $R_{10}$ ratio is due to the variability of the organic carbon fluxes which are more closely coupled to the variability of the drainage intensity than it is the case for the fluxes of inorganic carbon.

One can note (Table 1) that DOC to POC ratio $\left(R_{\mathrm{DP}}\right)$ are on average $0.4 \pm 0.1$ for 1994-1995. However, on an annual basis, the ratios are lower and exhibit less variability, e.g., $0.9 \pm 0.3$. The highest ratios corresponded to the lowest discharges. Such observations indicate that high discharge and subsequent mechanical erosion promote sediment fluxes and POC transport in the Rhône River.

\subsection{Net Flux and Lability of POC}

In order to contribute to a better estimate of the carbon budget in the Gulf of Lions, we also classified calculated TSM and POC (one value per day over the period 1987-1996) into groups representing samples within nine specific ranges of TSM from 5 to $5000 \mathrm{mg} \mathrm{L}^{-1}$ (Table 3) according to the classification of
Meybeck [1982]. Labile (susceptible to bacterial degradation) particulate organic carbon (LPOC) was subsequently estimated according to the assessment of Ittekot [1988], who reported for each specific TSM range, a relative LPOC contribution. The labile fraction, defined as the carbon equivalent of measured sugars and amino acids, is relatively more abundant during periods of low sediment loads, whereas biodegraded organic substances dominate at high discharges [Ittekot and Laane, 1991]. As pointed out by Smith and Hollibaugh [1993], this is a broad simplification since other classes of compounds such as lipids, nucleic acids, or lignocellulose are available to bacteria as well [Tranvick and Höefle, 1987], and therefore uncertainties (and likely underestimations) are associated to such evaluation.

Over the 10-year estimation, the results showed that LPOC transport ranged from 0.9 to $4.6 \times 10^{9}$ moles $\mathrm{C} \mathrm{yr}^{-1}$ (average 2.7 $\times 10^{9}$ moles $\mathrm{C} \mathrm{yr}^{-1}$ ), accounting for 14 to $23 \%$ (av. $18 \%$ ) of the bulk POC (Table 4). Most of the LPOC was found for TSM concentrations ranging between 15 and $1500 \mathrm{mg} \mathrm{L}^{-1}$ (Table 3). These labile fractions are likely to be transformed into bacterial biomass and respired for an other part as $\mathrm{CO}_{2}$ in estuarine and 

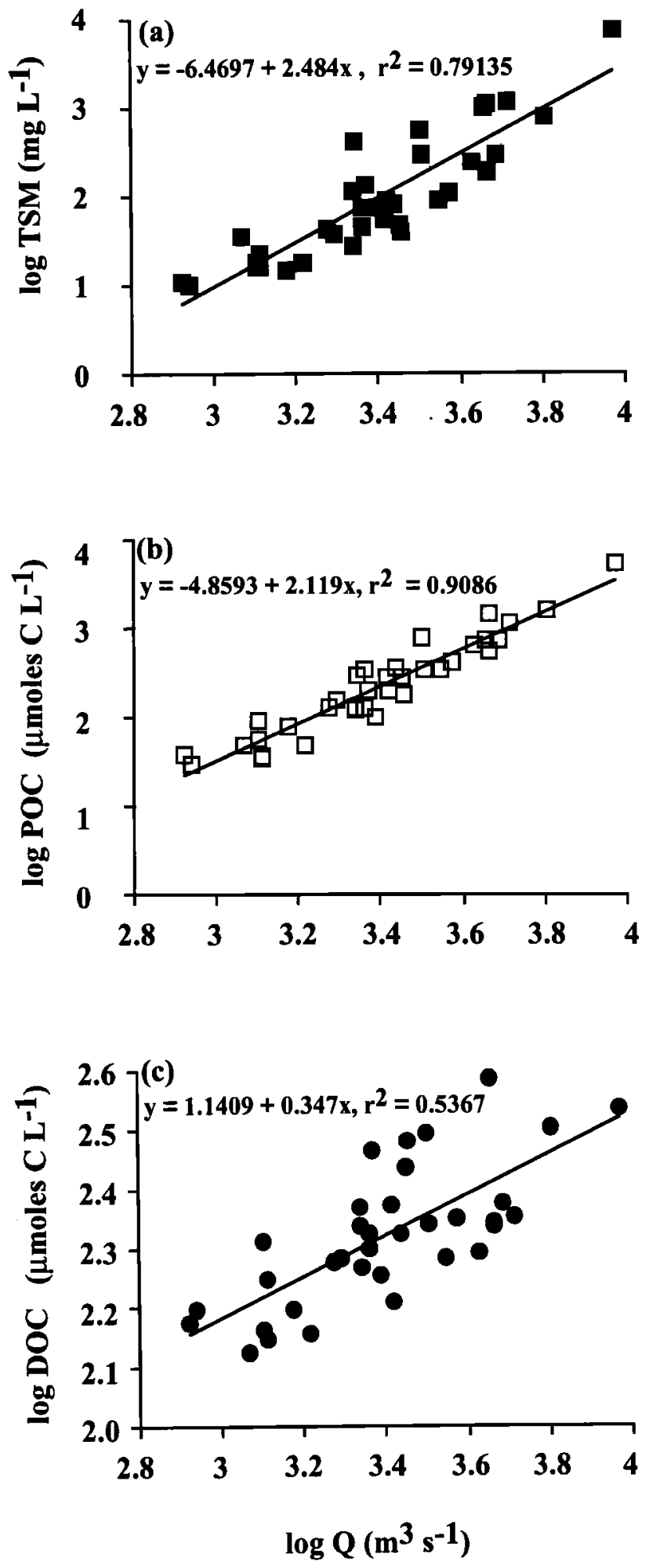

Figure 5. Relationships between the daily discharge rate $\left(\mathrm{m}^{3} \mathrm{~s}^{-}\right.$ 1) and (a) TSM (mg L ${ }^{-1}$ ) in t, (b) POC, (c) DOC concentrations $(\mu \mathrm{M}$ C) at the sampling station during June 1994 to May 1995 (n $=35$ ). Regression equations are provided with the $95 \%$ confidence intervals for the regression parameters. All the equations are highly significant $(p<0.001)$. These equations together with the Ferguson's [1987] factors were used for the TSM, POC, and DOC flux calculations over the period 19871995. (See also Table 2.)

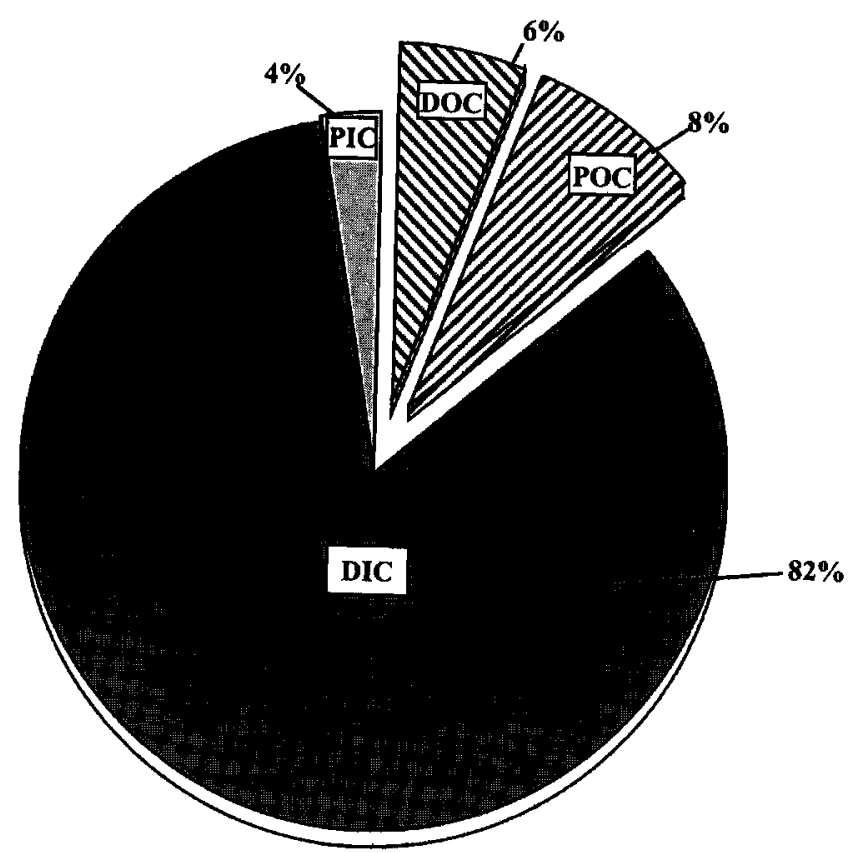

Figure 6. Pie diagram of the averaged relative abundance (in percent) of DOC, POC, DIC, and PIC in the Rhône River carbon fluxes.

coastal waters within a few days. The remaining "refractory particulate organic carbon" (RPOC) fraction (0.34-2.9 x 1010 moles $\mathrm{C} \mathrm{yr}^{-1}$; average $1.3 \times 10^{10}$ ) might be deposited in and off the shelf southwestward by the nepheloid layers offshore as it was pointed out for TSM [Durrieu de Madron et al., 1990]. Another part of the RPOC might be also converted to DOC through microbial degradation [Moran and Hodson, 1990] or by desagregation as it was suggested by Karl et al. [1988] for marine particles.

\subsection{Net Flux and Lability of DOC}

LDOC might be utilized by bacteria for their biomass production and their respiration within days [Tranvick and Höefle, 1987; Sondergaard and Middelboe, 1995; Amon and Benner, 1996]. As land-derived dissolved organic compounds have already undergone some biotic and abiotic transformations before entering the coastal waters, this residual material is likely less labile than freshly produced autochthonous substrates in marine ecosystems [Hobbie, 1988; Amon and Benner, 1996]. However, different processes such as photochemical oxidation [Mopper et al., 1991], ectoenzymatic activity and grazing [Tranvick, 1992, and references therein] may increase the bioavailability of riverine organic matter. Although, LDOC is likely to vary with the river discharge, there is currently no global accurate estimation of river derived-LDOC. Studies related to laboratory incubation experiments of total riverine DOC suggested that LDOC varies from 5 to 22\% of DOC [Servais et al., 1987; Tranvick and Höefle, 1987; Sondergaard and Middelboe, 1995; Sondergaard et al., 1995]. We retained an average of LDOC/DOC ratio of $15 \%$, which is in line with the estimate (15-30\%) given by Spitzy and Ittekot [1991] for riverborne DOC.

By applying a LDOC/DOC ratio of $15 \%$, the LDOC flux in the Rhône River would average $0.16 \times 10^{10}$ moles $\mathrm{C} \mathrm{yr}^{-1}$. The 
Table 3. Range of Total Suspended Matter (TSM) Corresponding Percentage of Data and Contribution of Each TSM Class to Labile Particulate Organic Carbon (LPOC) Fluxes Calculated From Daily 10- Year Rhône River Discharge (1987-1996)

\begin{tabular}{lcc}
\hline TSM Range, $\mathrm{mg} \mathrm{L}^{-1}$ & $\begin{array}{c}\text { Percentage } \\
\text { of Data }\end{array}$ & Contribution \\
& of LPOC Fluxes, \% \\
\hline $0-15$ & 32 & 3 \\
$15-50$ & 30 & 20 \\
$50-150$ & 23 & 24 \\
$150-500$ & 13 & 27 \\
$500-1500$ & 2 & 21 \\
$1500-5000$ & 0.3 & 8 \\
\hline
\end{tabular}

remaining refractory-DOC (RDOC) can be calculated as the difference between DOC and LDOC and equals $0.92 \times 10^{10}$ moles $\mathrm{C} \mathrm{yr}^{-1}$. This number is likely underestimated, since some RPOC might be converted in RDOC (see above). This refractory organic matter is supposed to be more slowly oxidized offshore by bacteria or mixed to the marine DOC-bulk.

Bacterial growth efficiency (BGE), which is the result of bacterial production (BP) and bacterial respiration (BR), can be defined by the following:

$$
\mathrm{BGE}=\mathrm{BR} \times(\mathrm{BR}+\mathrm{BP}) / \mathrm{BP} .
$$

For bacteria growing on riverborne material, the bacterial carbon demand $(B C D=B P+B R)$, could be estimated as the sum LDOC + LPOC. Then, we can estimate from equations (6) and (7) the carbon dioxide produced through bacterial respiration.

$$
\begin{aligned}
& \mathrm{CO}_{2} \text { respired from } \mathrm{LDOC}=(1-\mathrm{BGE}) \times \mathrm{LDOC} \\
& \mathrm{CO}_{2} \text { respired from } \mathrm{LPOC}=(1-\mathrm{BGE}) \times \mathrm{LPOC}
\end{aligned}
$$

Applying a BGE of $0.24(\mathrm{sd}=0.23)$ [del Giorgio et al., 1997] for the bacterial consumption of riverine-derived labile organic carbon (Table 4), then, at least 0.12 (sd 0.1) and 0.21 (sd 0.2) x $10^{10}$ moles $\mathrm{CO}_{2} \mathrm{yr}^{-1}$ could be rapidly (days) produced during transport in the estuary or in the nearshore environment through bacterial respiration from LDOC and LPOC, respectively.

\subsection{Organic Metabolism in the Coastal System}

The annual primary production (based on $14 \mathrm{C}$ assimilation technique with incubation times ranging from 10 to 24 hours) and integrated to the deep chlorophyll maximum (DCM) within the dilution zone of the Rhône (most of the shelf) was estimated to 12.4 moles $\mathrm{C} \mathrm{m}^{-2} \mathrm{yr}^{-1}$ [Christaki et al, 1996; Yoro et al., 1997; Van Wambeke et al., 1998; Conan et al., 1999; Diaz et al., 1999; Table 5]. We estimated this figure to the net primary production (NPP), since ${ }^{14} \mathrm{C}$-based measurements were made over a incubation period higher than 6 hours [Williams et al., 1996]. Similarly, on the shelf, recent studies indicated a bacterial production integrated to the DCM of 2.1 moles $\mathrm{C} \mathrm{m}^{-2} \mathrm{yr}^{-1}$ (Table 5). These values give rise for the entire shelf $\left(11 \times 10^{9} \mathrm{~m}^{2}\right)$ to a secondary and a primary productions of $2.3 \times 10^{10}$ moles $\mathrm{C} \mathrm{yr}^{-1}$ and $13.6 \times 10^{10}$ moles $\mathrm{C} \mathrm{yr}^{-1}$, respectively (Table 6). Buscail et al. [1990] estimated accumulation and mineralization rates at the sediment/water interface to be $0.48 \times 10^{10}$ moles $C y^{-1}$ and $1.5 \times$ $10^{10}$ moles $\mathrm{C} \mathrm{yr}^{-1}$, respectively (Table 6). Then, for the entire shelf, assuming a BGE of $0.24 \pm 0.23$ [del Giorgio et al., 1997], the BCD would be $9.6 \pm 10 \times 10^{10}$ moles $\mathrm{C} \mathrm{yr}^{-1}$ in the water

Table 4. Labile Particulate Organic Carbon (LPOC) Fluxes Calculated as the Carbon Contributed by Sugars and Amino Acids to Total POC [after Ittekot, 1988]

\begin{tabular}{cccc}
\hline Year & $\begin{array}{c}\text { LPOC Fluxes, } \\
10^{9} \text { moles C yr }\end{array}$ & $\begin{array}{c}\text { LPOC Fluxes, } \\
\text { \% of POC }\end{array}$ & $\begin{array}{c}\text { RPOC Fluxes, } \\
10^{10}{\text { moles C } \text { yr }^{-1}}^{-1}\end{array}$ \\
\hline 1987 & 2.76 & 19 & 1.16 \\
1988 & 3.08 & 17 & 1.50 \\
1989 & 0.90 & 21 & 0.34 \\
1990 & 1.41 & 23 & 0.47 \\
1991 & 1.47 & 21 & 0.57 \\
1992 & 2.45 & 19 & 1.04 \\
1993 & 3.63 & 14 & 2.19 \\
1994 & 4.62 & 14 & 2.89 \\
1995 & 3.39 & 17 & 1.70 \\
1996 & 3.04 & 16 & 1.66 \\
$10-$ year average & & & $1.3 \pm 0.8$ \\
\hline
\end{tabular}

Refractory particulate organic carbon (RPOC) fluxes are calculated as the difference between POC and LPOC fluxes. 

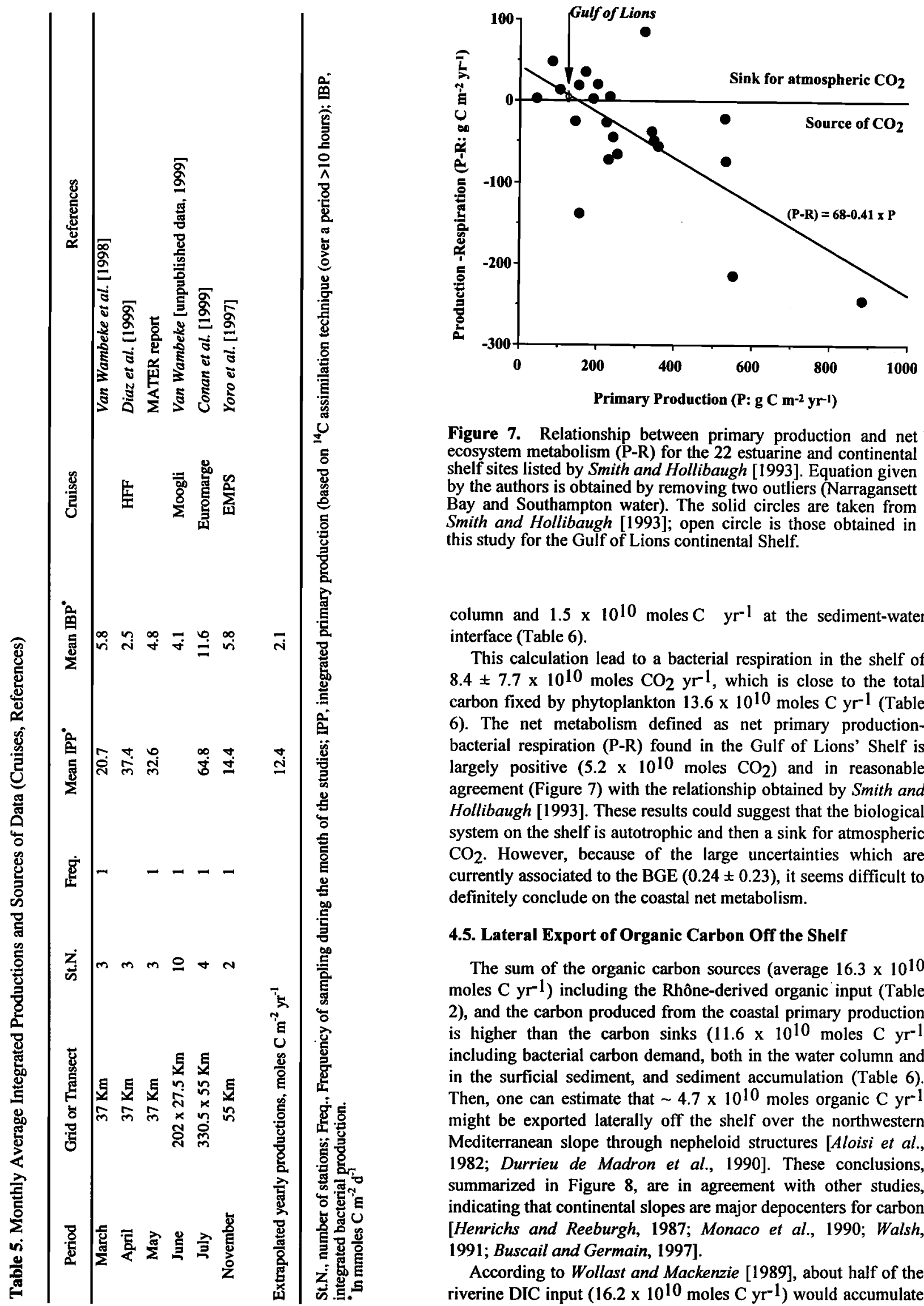

Figure 7. Relationship between primary production and net ecosystem metabolism (P-R) for the 22 estuarine and continental shelf sites listed by Smith and Hollibaugh [1993]. Equation given by the authors is obtained by removing two outliers (Narragansett Bay and Southampton water). The solid circles are taken from Smith and Hollibaugh [1993]; open circle is those obtained in this study for the Gulf of Lions continental Shelf.

column and $1.5 \times 10^{10}$ moles $\mathrm{C} \mathrm{yr}^{-1}$ at the sediment-water interface (Table 6).

This calculation lead to a bacterial respiration in the shelf of $8.4 \pm 7.7 \times 10^{10}$ moles $\mathrm{CO}_{2} \mathrm{yr}^{-1}$, which is close to the total carbon fixed by phytoplankton $13.6 \times 10^{10}$ moles $\mathrm{C} \mathrm{yr}^{-1}$ (Table 6). The net metabolism defined as net primary productionbacterial respiration (P-R) found in the Gulf of Lions' Shelf is largely positive $\left(5.2 \times 10^{10}\right.$ moles $\left.\mathrm{CO}_{2}\right)$ and in reasonable agreement (Figure 7) with the relationship obtained by Smith and Hollibaugh [1993]. These results could suggest that the biological system on the shelf is autotrophic and then a sink for atmospheric $\mathrm{CO}_{2}$. However, because of the large uncertainties which are currently associated to the BGE $(0.24 \pm 0.23)$, it seems difficult to definitely conclude on the coastal net metabolism.

\subsection{Lateral Export of Organic Carbon Off the Shelf}

The sum of the organic carbon sources (average $16.3 \times 10^{10}$ moles $\mathrm{C} \mathrm{yr}^{-1}$ ) including the Rhône-derived organic input (Table 2 ), and the carbon produced from the coastal primary production is higher than the carbon sinks $\left(11.6 \times 10^{10}\right.$ moles $\mathrm{C} \mathrm{yr} \mathrm{r}^{-1}$ including bacterial carbon demand, both in the water column and in the surficial sediment, and sediment accumulation (Table 6). Then, one can estimate that $\sim 4.7 \times 10^{10}$ moles organic $\mathrm{C} \mathrm{yr}^{-1}$ might be exported laterally off the shelf over the northwestern Mediterranean slope through nepheloid structures [Aloisi et al., 1982; Durrieu de Madron et al., 1990]. These conclusions, summarized in Figure 8, are in agreement with other studies, indicating that continental slopes are major depocenters for carbon [Henrichs and Reeburgh, 1987; Monaco et al., 1990; Walsh, 1991; Buscail and Germain, 1997].

According to Wollast and Mackenzie [1989], about half of the riverine DIC input $\left(16.2 \times 10^{10}\right.$ moles $\left.\mathrm{C} \mathrm{yr}^{-1}\right)$ would accumulate 
Table 6. Estimates of Bacterial Production (BP), Primary Production (PP), Bacterial Carbon Demand $(B C D)$ and Bacterial Respiration (BR) in the water column for the entire shelf $\left(11 \times 10^{9} \mathrm{~m}^{2}\right)$ in the Gulf of Lions

\begin{tabular}{lcc}
\hline & Water Column & Water-Sediment Interface \\
\hline $\mathrm{BP}, 10^{10}$ moles $\mathrm{C} \mathrm{yr}$ & \\
$\mathrm{PP}, 10^{10}$ moles $\mathrm{C} \mathrm{yr}^{-1}$ & 2.3 & \\
$\mathrm{BCD}, 10^{10}$ moles C yr $^{-1}$ & 13.6 & 1.5 \\
$\mathrm{BR}, 10^{10}{\text { moles } \mathrm{C} \mathrm{yr}^{-1}}^{-1}$ & 9.6 & 1.1 \\
\hline
\end{tabular}

Also given are at the water sediment-interface, $\mathrm{BCD}$ which was approximated to the mineralization rates ( $\mathrm{POC}->\mathrm{DOC}+$ $\mathrm{CO}_{2}$ ) calculated by Buscail et al. [1990] and BR. The accumulation of organic carbon at the interface was $0.48 \times 10^{10}$ moles C $\mathrm{yr}^{-1}$ [Buscail et al., 1990]. BCD and BR were calculated from bacterial production and BCD (see references Table 5) and assuming a bacterial growth efficiency of 0.24 [del Giorgio et al., 1997]. Assuming a standard deviation of 0.23 for $B G E$, the errors would be (in $10^{10}$ moles $\mathrm{C} \mathrm{m}^{-2} \mathrm{yr}^{-1}$ ) $10,7.7$, and 1.1 for $B C D, \mathrm{BR}_{\text {water, }}$ and $\mathrm{BR}_{\text {sed., }}$ respectively.

in nearshore environment (in addition to PIC $=0.82 \times 10^{10}$ moles

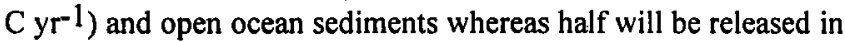
the water column and eventually returned in the atmosphere. These numbers seem to be consistent with the carbonate accumulation of $\sim 3 \times 10^{10}$ moles $\mathrm{C} \mathrm{yr}^{-1}$ found by direct measurements in the eastern part of the shelf [unpublished data, $R$. Buscail, 1998].

\subsection{Relative Importance of the Rhône River Fluxes in the Mediterranean Sea}

The main source of organic carbon in the Mediterranean Sea is the internal primary production, which produces $20-26 \times 10^{12}$ moles C yr-1 [Minas et al., 1988; Antoine et al., 1995]. TOC import from the Atlantic Ocean (125 x $10^{10}$ [Copin-Montégut, 1993]) remains the main external source of organic carbon to Mediterranean Sea. Organic carbon depositions due to rains and aerosols into the Mediterranean Sea could range from 10 to $20 \mathrm{x}$ $10^{10}$ moles C $\mathrm{yr}^{-1}$ [Loÿé-Pillot et al., 1992; Copin-Montégut, 1993], the net mass transfer from the Black Sea being 11 to $12 \mathrm{x}$ $10^{10}$ moles $\mathrm{C} \mathrm{yr}^{-1}$ [Polat and Tugrul, 1996]. Then, the Rhône River-TOC input is 2 orders of magnitude lower than TOC import from the Atlantic Ocean and $\sim 1$ order of magnitude lower than TOC atmospheric depositions (Table 7).

The same trend is observed for TSM between the Rhône and the atmospheric inputs. The inputs of all the Mediterranean Rivers

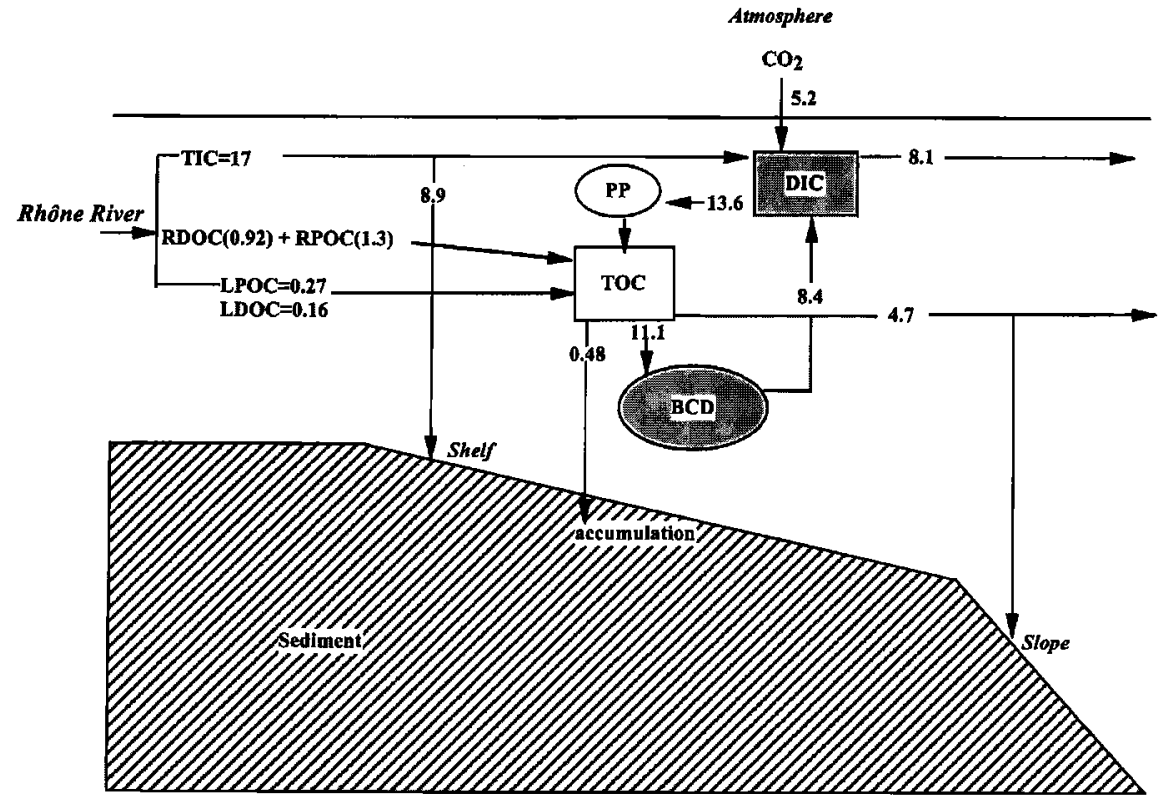

Figure 8. Description of the carbon cycle proposed for the continental shelf in the Gulf of Lions in the northwestern Mediterranean Sea. Annual fluxes are in $10^{10}$ moles $C y^{-1}$. Data from Table 1 and 2 are in boldfaced type. LDOC, labile DOC, RDOC, refractory DOC; LPOC, labile POC, RPOC, refractory POC. DIC, dissolved inorganic carbon; PP, primary production. $\mathrm{BCD}$, bacterial carbon demand (bacterial production/ bacterial growth efficiency) calculated from bacterial production (Table 6) and a bacterial growth efficiency of 0.24 (sd 0.23 ) [del Giorgio et al., 1997]. Bacterial production was measured after ${ }^{3} \mathrm{H}$-thymidine incorporation technique. 
Table 7. Summary of the Estimated Sources, Standing Crop, and Residence Times of TOC and DIC in the Mediterranean Sea

\begin{tabular}{|c|c|c|c|c|}
\hline$\times 10^{10} \mathrm{~mol} \mathrm{C} \mathrm{yr}^{-1}$ & TOC & DIC & $\mathrm{LTOC}=\mathrm{LDOC}+\mathrm{LPOC}$ & $\mathrm{CO}_{2} / \mathrm{LTOC}$ \\
\hline Rivers* & $20-83$ & $144-168$ & $3.3-13.5$ & $2.7-11$ \\
\hline Black Sea $^{\dagger}$ & $11-12$ & 105 & & \\
\hline Atmosphere $^{\ddagger}$ & $10-20$ & $35-185$ & & \\
\hline Atlantic Ocean & 125 & -27 & & \\
\hline Standing crop & 24,700 & 961,000 & & \\
\hline Residence time (yr) & $103-149$ & 2098-3383 & & \\
\hline
\end{tabular}

TOC and DIC standing crops were calculated according a DOC concentration of 70 and $54 \mu \mathrm{M} \mathrm{C}$ for 0-200 m and deep waters (POC was considered as negligible), respectively and an average DIC concentration of $2190 \mu \mathrm{M} \mathrm{C}$ for DIC (from data of Copin-Montégut and Avril, 1993 ; Copin-Montégut, 1993) and a Med. Sea volume of $4.38 \times 10^{15} \mathrm{~m}^{3}$. LTOC was calculated as the addition of $\mathrm{LPOC}$ and $\mathrm{LDOC}_{1} \mathrm{LCO}_{2}\left(\mathrm{CO}_{2}\right.$ produced through bacteria respiration of LTOC

Copin-Montégut [1993] and Ludwig et al. [1998].

$\dagger$ Polat and Tugrul [1996].

\$Löé-Pillot et al. [1992].

${ }^{8}$ Copin-Montégut [1993].

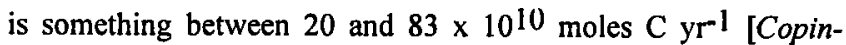
Montégut, 1993; Ludwig et al., 1998]. Then, these results indicate that atmospheric depositions, rivers, and Black Sea organic contributions are within the same order of magnitude, although the riverine input remains predominant. An important point is also that our estimates suggest that $0.33 \times 10^{10}$ moles $\mathrm{C} \mathrm{yr}^{-1}$ of $\mathrm{CO}_{2}$ might be rapidly produced from the bacterial respiration on labileRhône TOC. Extended to the whole Mediterranean, 2.6-11 x $10^{10}$ moles $\mathrm{CO}_{2} \mathrm{yr}^{-1}$ might be rapidly respired by bacteria nearshore in the Mediterranean (Table 7).

The Mediterranean Sea volume is $\sim 4.38 \times 10^{15} \mathrm{~m}^{3}$ [Dietrich et al., 1980], assuming DOC constitutes most of the TOC with concentrations of $\sim 70 \mu \mathrm{M} \mathrm{C}$ in the layer $0-200 \mathrm{~m}$ and $\sim 54 \mu \mathrm{M} \mathrm{C}$ below [Copin-Montégut and Avril, 1993], the Mediterranean standing crop of TOC (we consider POC to be negligible regarding DOC stock) is $\sim 247 \times 10^{12}$ moles $C$ (Table 7). One can estimate (by dividing the DOC reservoir by overall input) that the residence time for DOC in the Mediterranean Sea is something between 103 and 149 years (Table 7), which is close to the mixing time of Mediterranean water ( 100 years [Lacombe and Richez, 1982]). It is important to note that the fluvial loading of TOC to the Mediterranean Sea comprises $0.08-0.3 \%$ of the standing crop of TOC, whereas the Rhône River contribution is $\sim 0.01 \%$. For comparison, taking Smith and Hollibaugh [1993] data, this ratio in the world ocean is $\sim 0.02 \%$. This highlights that the Rhône River, and more generally the rivers play an important role on the Mediterranean Sea carbon cycle.

The carbonate sedimentation of inorganic carbon in the sediments is $\sim 20 \times 10^{10}$ moles $\mathrm{C} \mathrm{yr}^{-1}$ [Copin-Montégut, 1993]. Referring to rainwater alkalinity data obtained by Loÿé-Pillot and Morelli [1988], Copin-Montégut [1993] estimated to 35-185 x $10^{10}$ moles $\mathrm{C} \mathrm{yr}^{-1}$ the average rain input of inorganic carbon supplied to the Mediterranean. This estimate is close to the overall Mediterranean river inputs (144.168 $\times 10^{10}$ moles $\left.\mathrm{C} \mathrm{yr}^{-1}\right)$ and significantly contribute to the Mediterranean outflow (-4.6 to -6.1 $\times 10^{12}$ moles $C \mathrm{yr}^{-1}$ ) to the Atlantic [Copin-Montégut, 1993; Ludwig et al., 1998]. We estimated that the Rhône River and more generally Mediterranean river inputs contribute $0.16 \times 10^{-1} \%$ and $0.17 \times 10^{-2} \%$, respectively, of the Mediterranean inorganic carbon reservoir (961 x $10^{13}$ moles $\mathrm{C} \mathrm{yr}^{-1}$ : Table 7).
Acknowledgments. The authors are very grateful to $D$. Pont from CNRS-Arles for reporting daily discharge rates related to the Rhône River and for logistic support during the sampling operations. We acknowledge A. Bianchi, R. Buscail, C. Copin-Montégut, H. Grout, W. Ludwig, and S. Peruzzi for constructive comments on the manuscript. We appreciated the help of S. W. Smith and two anonymous reviewers for improving the revised version of the manuscript and R. I. Ferguson for the calculation of fluxes. Daily precipitation data were provided by "Direction interrégional sud-est centre départemental des Bouches du Rhône-Météo-France". This study was partly supported by the European Commission's Marine Science and Technology (MAST) Programme under contract MAS2-CT94-0090.

\section{References}

Aloisi, J. C., J. P. Cambon, , J. Carbonne, G. Cauwet, C. Millot, A. Monaco, and $\mathrm{H}$. Pauc, Origine et rôle du népheloìde profond dans le transfert des particules au milieu marin. Application au Golfe du Lion, Oceanol. Acta, 5, 481-491, 1982.

Amon, M. W., and R. Benner, Bacterial utilization of different classes of dissolved organic matter, Limnol. Oceanogr., 41, 41-51, 1996.

Antoine, D., A. Morel, and J. M. André, Algal pigment distribution and primary production in the eastern Mediterranean as derived from coastal zone color scanner observations, J. Geophys, Res., 100, 16, 193-16, 209, 1995.

Berner, R. A., Atmospheric $\mathrm{CO}_{2}$ levels over phanerozoic time. Science, 249, 1382-1386, 1990.

Bray, N. A., J. Ochoa, and T. H. Kinder, The role of interface in exchange through the Strait of Gibraltar. J. Geophys. Res., 100, 755-776, 1995.

Berner, R. A., A. C. Lasaga, and R. M. Garrels, The carbonate-silicate geochemical cycle and its effect on atmospheric carbon dioxide over the past 100 millions years, Am. J. Sci., 283, 641-683, 1983.

Bryden, H. L., and T. H. Kinder, Gibraltar experiment: a plan for dynamic and kinematic investigations of strait mixing, exchange and turbulence, in Pelagic Mediterranean oceanography, edited by H. J. Minas and P. Nival, Oceanol. Acta, NSP 9, 29-40, 1988.

Buscail, R., and C. Germain, Present day organic matter sedimentation on the NW Mediterranean margin: Importance of shelf export, Limnol. Oceanogr., 42, 217-229, 1997.

Buscail, R., R. Pocklington, R. Daumas, and L. Guidi, Fluxes and budget 
of organic matter in the benthic boundary layer over the northwestern Mediterranean margin, Cont. Shelf. Res., 10, 1089-1122, 1990.

Cauwet, G., HTCO method for dissolved organic carbon analysis in seawater: influence of catalyst on blank estimation, Mar. Chem., 47, 55-64, 1994.

Cauwet, G., F. Gadel, M. M. de Souza Sierra, O. Donard, and M. Ewald,. Contribution of the Rhône River to organic carbon input to the northwestern Mediterranean Sea, Cont. Shelf Res. 10, 1025-1037, 1990.

Christaki, U., F. Van Wambeke, E. D. Christou, P. Conan, and R. Gaudy, Food web structure variability in the surface layer, at a fixed station influenced by the northwestern Mediterranean Current, Hydrobiologia, 321, 145-153, 1996.

Clair, T. A., and J. M. Ehrman, Variations in discharge and dissolved organic carbon and nitrogen export from terrestrial basins with changes in climate: A neutral network approach, Limnol. Oceanogr., 4I, 921927, 1996.

Conan, P., C. Turley, E. Stutt, M. Pujo-Pay, and F. Van Wambeke, Relationship between phytoplankton efficiency and the proportion of bacterial production to primary production in the Mediterranean Sea, Aquat. Microb. Ecol., 17, 131-144, 1999.

Copin-Montégut, C., Alkalinity and carbon budgets in the Mediterranean, Global Biogeochem. Cycles, 7, 915-925, 1993.

Copin-Montégut, G., and B. Avril, Vertical distribution and temporal variation of dissolved organic carbon in the North-Western Mediterranean Sea, Deep Sea Res., 40, 1963-1972, 1993.

Cruzado, A., and Z. R. Velasquez, Nutrients and phytoplankton in the Gulf of Lions, Cont. Shelf. Res., 10, 931-942, 1990.

del Giorgio, P.A., J. A. Cole, and A. Cimbleris, Respiration rates in bacteria exceed phytoplankton production in unproductive aquatic systems, Nature, 385, 148-151, 1997.

Diaz, F., P. Raimbault, and P. Conan, Carbon and nitrogenutilization by phytoplankton during spring in a Mediterranean coastal zone (Gulf of Lions): evidence of small-scale variability, Cont. Shelf Res., in press, 1999.

Dietrich, G., K. Kalle, W. Krauss, and G. Siedler, General Oceanography, 2nd ed., John Wiley, New York, 1980.

Durrieu de Madron, X., F. Nyffeler, and C. H. Godet, Hydrographic structure and nepheloid spatial distribution in the Gulf of Lions continental margin, Cont. Shelf. Res., 10, 915-929, 1990

Ferguson, R. I., Accuracy and precision of methods for estimating river loads, Earth Surf. Processes Landforms, 12, 95-104, 1987.

Hansen, D. V., and M. Rattray, New dimensions in estuary classification, Limnol. Oceanogr., 11, 319-326, 1966.

Heinrichs, S., and W. S. Reeburgh, Anaerobic mineralization of marine sediment organic matter: Rates and the role of anaerobic processes in the oceanic carbon economy, Geomicrobiol. J., 5, 191-237, 1987.

Hobbie, J. E., A comparison of the ecology of planktonic bacteria in fresh and salt water, Limnol. Oceanogr., 33, 750-764, 1988.

Ibanez, C., D. Pont, and N. Prat, Characterization of the Ebre and Rhône estuaries: A basis for defining and classifying salt-wedge estuaries, Limnol. Oceanogr., 42, 89-101, 1997.

Ittekot, V., Global trends in the nature of organic matter in river suspensions, Nature, 332, 436-438, 1988.

Ittekot, V., and R. W. P. M. Laane, Fate of riverine particulate organic matter, Biogeochemistry of European rivers, in Biogeochemistry of Major World Rivers, SCOPE Rep. 42, edited by E. T. Degens, S. Kempe, and J. E. Richey, pp. 233-243, John Wiley, New York, 1991.

Justic, D., N. N. Rabalais, and R. E. Turner, Effects of climate change on hypoxia in coastal waters: $\mathrm{A}$ doubled $\mathrm{CO}_{2}$ scenario for the northem Gulf of Mexico, Limnol. Oceanogr., 41, 992-1003, 1996.
Kao, S. J., and K. K. Liu, Particulate organic carbon export from a subtropical mountainous river (Lanyang Hsi) in Tajwan, Limnol. Oceanogr., 4l, 1749-1757, 1996.

Kao, S. J., and K. K. Liu, Fluxes of dissolved and nonfossil particulate organic carbon from an oceania small river (Lanyang $\mathrm{Hsi}$ ) in Taiwan, Biogeochemistry, 39, 255-269, 1997.

Karl, D. M., G. A. Knauer, and M, H. John, Downward flux of particulate organic matter in the ocean: A particle decomposition paradox,Nature, 332, 438-440, 1988.

Kempe, S., M. Pettine, and G. Cauwet, Biogeochemistry of European rivers, in Biogeochemistry of Major World Rivers, SCOPE Rep. 42, edited by E. T. Degens, S. Kempe, and J. E. Richey, pp. 169-211, John Wiley, New York, 1993.

Lacombe H., and C. Richez, The regime of the Strait of Gibraltar, in Hydrodynamics of Semi-Enclosed Seas, edited by J. C. J. Nihoul, pp 13-14, Elsevier Sci., New York, 1982.

Loye-Pillot, M. D., and J. Morelli, Fluctuations of ionic composition of precipitations collected in Corsica related to changes in the origins of incoming aerosols, J. Aerosol Sci., 19, 577-585, 1988.

Loÿé-Pillot, M. D., G. Cauwet, A. Spitzy, and J. M. Martin, Preliminary results on atmospheric wet deposition of organic carbon and nitrogen in Corsica, in Water Pollution Research Report 28, EROS 2000, Third Workshop, edited by J. M. Martin and H. Barth, pp. 519-532, Comm. of the Eur. Comm., Brussels, 1992.

Ludwig, W., P. Amiotte-Suchet, and J. L. Probst. River discharges of carbon to the world's oceans: Determining local inputs of alkalinity and of dissolved and particulate organic carbon. C.R. Acad. Sci. Paris, Ser. II, 323, 1007-1014, 1996a.

Ludwig, W., J. L. Probst, and S. Kempe, Predicting the oceanic input of organic carbon by continental erosion, Global Biogeochem. Cycles, 10 , 23-41, 1996b.

Ludwig, W., P. Amiotte-Suchet, and J-L. Probst, Atmospheric $\mathrm{CO}_{2}$ consumption by continental erosion: Present day controls and implications for the last glacial maximum, Global Planet. Change, 1617, 107-120, 1998.

Mantoura, R. F.C., and E. M. S. Woodward, Conservation behaviour of riverine dissolved organic carbon in the Severn Estuary: Chemical and geochemical implications, Geochim. Cosmochim. Acta, 47, 1293-1309, 1983.

Margat, J. (Ed.), L'eau dans le bassin méditerranéen, situation et prospective, in Les Fascicules du Plan Bleu, vol. 6, 196 pp., Economica, Paris, 1992.

Meybeck, M., Carbon, nitrogen and phosphorus transport by world rivers, Am. J. Sci., 282, 401-450, 1982.

Meybeck, M., Global chemical weathering of surficial rocks estimated from river dissolved loads, Am. J. Sci., 287, 401-428, 1987.

Miller, J. R., and G. L. Russel, The impact of global warming on river runoff, J. Geophys. Res., 97, 2757-2764, 1992.

Milliman, J. D., and J. P. M. Syvitsky, Geomorphic/tectonic control of sediment discharge to the ocean: The importance of small mountains rivers, J. Geol., 100, 525-544, 1992.

Millot, C., Circulation in the western Mediterranean Sea, Oceanol. Acta, 10, 143-149, 1987.

Minas, H. J., M. Minas, B. Coste, J. Gostan, P. Nival, and M. C. Bonin, Production de base et de recyclage; une revue de la problématique en Méditerranée Nord occidentale, Oceanol. Acta, 9, 155-162, 1988.

Ministère de l'Environnement, Annuaire de la qualité desEaux, Rivières et Canaux 1980, Bassin Rhône-Méditerranée-Corse, vol. 6, 432 pp., Paris, 1980.

Monaco, A., P. Biscaye, J. Soyer, R. Pocklington, and S. Heussner, 
Particle fluxes and ecosystem response on a continental margin: The 1985-1988 Mediterranean ECOMARGE experiment, Cont. Shelf. Res., 10, 809-839, 1990.

Mopper, K., X. Zhou, D. J. Kieber, and R. J. Sikorski, Photochemical degradation of dissolved organic carbon and its impact on the oceanic carbon cycle, Nature, 353, 60-62, 1991.

Moran, M. A., and R. E. Hodson, Contributions of degrading Spartina alterniflora lignocellulose to the dissolved organic carbon pool of a salt marsh, Mar. Ecol. Prog. Ser., 62, 161-168, 1990.

Polat, C., and S. Tugrul, Chemical exchange between the Mediterranean and the black Sea via the Turkish straits, Bulletin de I'Institut Océanographique, vol. 17, pp. 167-186, CIESM Sciences Series, Monaco, 1996.

Pont, D., Les débits solides du Rhône à proximité de son embouchure: Données récentes (1994-1995), Rev. Geogr. Lyon, 72, 23-33, 1997.

Probst, J. L., P. Amiotte-Suchet, and Y. Tardy, Carbon river fluxes and weathering $\mathrm{CO}_{2}$ consumption in the Congo and Amazon river basins, Appl. Geochem., 9, 1-13, 1994.

Richey, J. E., J. Brock, R. J. Naiman, R. C. Wissmar, and R. F. Stallard, Organic carbon: Oxidation and transport in the Amazon River,Science, 207, 1348-1351, 1980.

Sempéré, R., and G. Cauwet, Dissolved and colloidal organic carbon in the Rhône Estuary: Comparison of the UV-Persulfate and HTCO methods, C. R. Acad. Sci., 317, 57-63, 1993.

Servais, P., G. Billen, and M. C. Hascoet, Determination of the biodegradable fraction of dissolved organic matter in waters, Water Res., 21, 445-450, 1987.

Sholkovitz, E. R., Flocculation of dissolved organic and inorganic matter during the mixing of river water and seawater, Geochim. Cosmochim. Acta, 40, 831-845, 1976.

Smith, S. V., and J. T. Hollibaugh, Coastal metabolism and the oceanic organic carbon balance, Rev. Geophys., 31, 75-89, 1993.

Smith, S. V., R. M. Chambers, and J.T. Hollibaugh, Dissolved and particulate nutrient transport though a coastal watershed-estuary system, J. of Hydrol., 176, 181-203, 1996.

Sondergaard, M., and M. Middelboe, A cross-system analysis of labile dissolved organic carbon, Mar. Ecol. Prog. Ser., 118, 283-294, 1995.

Sondergaard, M., B. Hansen, and S. Markager, Dynamics of dissolved organic carbon lability in a eutrophic lake, Limnol.Oceanogr., 40, 4654, 1995.

Spitzy, A., and V. Ittekot, Dissolved organic carbon in rivers, in Ocean Margin Processes in Global Change, edited by R. F. C.Mantoura, J. M. Martin, and R. Wollast, pp. 5-17, Wiley Interscience, New York, 1991.

Tan, F. C., and P. M. Strain, Carbon isotope ratios of particulate organic matter in the Gulf of St. Lawrence, J. Fish. Res. Board.Can., 36, 678$682,1979$.

Tanoue, E., Vertical distribution of dissolved organic carbon in the North Pacific as determined by the high-temperature catalytic oxidation method, Earth Planet. Sci. Lett., III, 201-216, 1992.
Thomas, A. J., Input of artificial radionuclides to the Gulf of Lions and tracing the Rhône influence in marine surface sediments, Deep Sea Res., 44, 577-595, 1997.

Thomas, C., G. Cauwet, and J. F. Minster, Dissolved organic carbon in the equatorial Atlantic Ocean, Mar. Chem., 49, 155-169, 1995.

Tranvick, L. J., and M. Höefle, Bacterial growth in mixed cultures on dissolved organic carbon from humic and clear waters, Appl. Environ. Microbiol., 53, 482-488, 1987.

Tranvick, L. J., Allochtonous dissolved organic matter as an energy source for pelagic bacteria and the concept of the microbial loop, Hydrobiologia, 229, 107-114, 1992.

Ünluata, Ü, T. Oguz, M. A. Latif, and E. Özsoy, On the physical oceanography of the Turkish Straits, NATO/ASI Series, in The Physical Oceanography of the straits, edited by J. L. Pratt, pp. 25-60, Kluwer Acad. Norwell, Mass., 1990.

Van Wambeke, F., F. Diaz, R. Sempéré, E. Dafner, P. Conan, M. Bianchi, and $P$. Raimbault, Variability of heterotrophic bacterial processes in NW Mediterranean Sea during spring (High Frequency Flux Experiment), paper presented at the 3rd MTP-II Mater Workshop "Variability of the Mediterranean Sea, Comm. of the Euro.Commun.," Rhodos, Greece Oct. 15-17, 1998.

Walsh, J. J., Importance of continental margins in the marine biogeochemical cycling of carbon and nitrogen, Nature, 350, 53-55, 1991.

Williams, P. J. Leb, C. Robinson, M. Sondergaard, A. M. Jespersen, T. L. Bentley, D. Lefêvre, K. Richardson, and B. Reeman, Algal ${ }^{14} \mathrm{C}$ on total metabolisms, 2, Experimental observations with the diatoms skeletonema costatum, J. Plankton, Res, 18, 1961-1974, 1996.

Wollast, R., and F. T. Mackenzie, Global biogeochemical cycles and climate, in Climate and Geo-Science, edited by A. Berger et al., pp. 453-473, Kluwer Acad. Norwell, Mass., 1989.

Yoro, S. C., R. Sempéré, C. Turley, M. A. Unanue, X. Durrieu de Madron, and $\mathrm{M}$. Bianchi, Cross-slope variations of organic carbon and bacteria in the Gulf of Lions in relation to water dynamics (northwestern Mediterranean), Mar. Ecol. Prog. Ser., 161, 255-264, 1997.

G. Cauwet, Laboratoire d'Océanographie Biologique, UMR 7621, Laboratoire Arago, BP 44, 66651 Banyuls sur mer Cedex, France. cauwet@arago.obs-banyuls.fr

B. Charrière, Centre de Formation et de Recherche sur l'Environnement Marin, CNRS/INSU UMR 5110, 52 Avenue de Villeneuve, F 66860 Perpignan Cedex, France. (charrier@univ-perp.fr)

R. Sempéré and F. Van Wambeke, Laboratoire de Microbiologie Marine, CNRS/INSU EP 2032, Case 907, Campus deLuminy, Route Léon Lachamps, Université de la Méditerranée, F-13 288 Marseille Cedex 9, France. (sempere@luminy.univ-mrs.fr)

(Received January 19, 1999; revised August 9, 1999 ; accepted August 24, 1999.) 